\title{
13 Forms of social capital in economics
}

\author{
The importance of heteronomous \\ networks in the Swiss field \\ of economists (1980-2000)
}

\author{
Thierry Rossier and Pierre Benz
}

\section{Introduction ${ }^{1}$}

In June 2017, Marion Fourcade gave a keynote lecture at the annual congress of the Swiss Society of Economics and Statistics in Lausanne, insisting in particular on the importance of ideological and political issues in guiding research in economics. During the time dedicated to questions, someone in the audience argued against Fourcade's statements:

I think there is a lot of heterogeneity in economics, and much of what you've said would maybe apply to some subfields of economics, but not so much to others. Think of pure series with equilibrium refinements, there is not much ideology there. Or also . . . if you think of the resource curse and conflict[s], and development, and these kinds of things, there are very few people holding ideological views on whether oil is good, or bad. . . . It's more like a technical question that you try to analyse with statistical methods. Or also the randomised control trials, for example. Very often, actually, the margin of manoeuvre ... where ideology comes in, in some fields, it's relatively small. ${ }^{2}$

This professional economist was arguing for economics to be of a "pure" nature. Economists often believe in the autonomy of the discipline, especially toward political issues. ${ }^{3}$ However, some scholars have stressed the importance of ideology and political orientation in guiding economists' preferences for research specialisations and methodologies, and being related to their departmental affiliation (Beyer \& Pühringer 2019; Horowitz \& Hughes 2017; Fourcade 2018). This denegation of politics and, more generally, of "power" (Lebaron 2000: 243) has been identified as a specific feature of the discipline. Being much more heteronomous than economists would often state, economics is in fact strongly embedded in the field of power (i.e. the field ${ }^{4}$ of the dominant of all the other fields; Bourdieu 1996a, 2005). Consequently, controversies at stake are not solved like in the most autonomous sciences, such as natural and life sciences 
(Benz 2019), but rather depend on recognition and consecration tied to the field of power (Lebaron 2018: 217). As a "trans-epistemic" field, economics has roots in academia, politics, business and the media, and economists located at different intersections of these fields often diverge in their accounts of what is good economics (Maesse 2015). In a more historical perspective, economics has been close to political and economic decision-makers for a long time (Fourcade 2009), but its autonomy might have increased in the more recent period due to the professionalisation and the internationalisation of the discipline, and the related dissociation from the nationally anchored public administration and political class (Schmidt-Wellenburg \& Lebaron 2018: 17-18; Fourcade 2006).

Economists differ regarding their internal (e.g. ties to other academic economists) and external (e.g. ties to actors in the political and private sectors) networks. The type, form and size of these networks are constitutive of a specific hierarchy between individuals and participate to structure the discipline. This perspective has only received little attention until now and only a few studies (Denord et al. 2011; Eloire 2014; Godechot \& Mariot 2004; Serino et al. 2017; Lunding et al. 2020) have focused on the power provided through network relations or, said otherwise, on social capital within fields. To our knowledge, except Klüger (2018; and in this volume), no research has systematically investigated the role of social capital in the economics profession and its effects on the relative autonomy of the field.

This chapter aims to investigate the structure and evolution of social capital within the field of economists in Switzerland, where the discipline is particularly internationalised (Rossier \& Bühlmann 2018) and where different elite groups are particularly close, cohesive and connected (Bühlmann et al. 2012). It relies on an original prosopographical database of all professors of economics at Swiss universities between 1980 and $2000(n=200)$, who constitute the dominant agents in the discipline and concentrate the most dominant resources in the field (Rossier 2017). In a first empirical part, we focus on the distinction and hierarchy between autonomous (i.e. internal) and heteronomous (external) forms of social capital. By means of multiple correspondence analysis (MCA), we identify two main oppositions of resources and profiles among economists. The principal opposition is based on the volume of extra-disciplinary network resources, and the secondary opposition is related to the volume of intradisciplinary configurations of social capital. In a second part, we centre on the evolution in the structure of the field from 1980 to 2000. Through class-specific MCA, we show that, despite the fact that intra-disciplinary social capital gains in importance in the recent period, extra-disciplinary social capital decidedly constitutes the key structuring logic along time. The chapter is organised as follows. First, we develop the notions of scientific field and social capital. Second, we present our sample and data, our methodology and our indicators of social capital. Third, in an empirical part, we focus on the structure of the field according to social capital logics and on the historical evolution of these dynamics. Finally, we summarise our main findings and open on new research perspectives. 


\section{Internal and external forms of social capital in the field of economists}

A scientific (or disciplinary) field such as economics is very often structured around an opposition between a scientific pole, linked to scientific capital ${ }^{5}-\mathrm{a}$ symbolic capital associated with internal scientific prestige and recognition and a society (or worldly) pole, related to external - academic (i.e. at the university level), political and economic - capitals. The overall volume of capitals detained also matters in these fields (Bourdieu 2004). Insights on economics show that this discipline often follows these two modes of structuration (Lebaron 2001; Schmidt-Wellenburg 2018). In scientific fields, the role of social capital must not be underestimated (Gingras 2012; Bühlmann et al. 2017), but, until now, this particular resource has been given little attention.

Bourdieu (1986: 248-249) defines social capital as follows:

Social capital is the aggregate of the actual or potential resources which are linked to possession of a durable network of more or less institutionalized relationships of mutual acquaintance and recognition - or in other words, to membership in a group - which provides each of its members with the backing of the collectivity-owned capital, a "credential" which entitles them to credit, in the various senses of the word.

Bourdieu considers social capital as the most important resource in any social space together with economic and cultural capitals. From a quantitative perspective, social capital depends on the size of the network of an individual and on the volume of capitals detained by other members of the network, understood as their more or less important integration to the field of power (Bourdieu 1996a). From a qualitative perspective, social capital is characterised by the nature of the capitals detained by the linked individuals. A high volume of social capital puts individuals in a rather favourable position within a given field since it tends to multiply the other detained capitals (Eloire 2018). While reflecting the importance of maintaining connections between members of certain fractions of the dominant class (Lenoir 2015), social capital can be considered as a resource that may generate symbolic capital within a field (De Nooy 2003), including a scientific field such as economics as a scientific discipline. In order to provide a better understanding of the structure of social capital in economics, this chapter differentiates between intra- and extra-disciplinary forms of social capital.

Intra-disciplinary social capital can be obtained through networks within the disciplinary field of economics. At the institutional level, social capital can be acquired through positions occupied at the top of powerful institutions, where individuals are linked to other powerful individuals. In scientific fields, it corresponds to the executive committee of disciplinary institutions or deanship in disciplinary departments (Bourdieu 2004). At the inter-personal level, social capital can be acquired through more or less intricate and institutionally formalised 
relations with other individuals engaged in the field of economists. These relations can be developed over a longer period of time and allow individuals to mobilise strong ties. Two types are of particular concern to us: relations developed through doctoral supervision of future economics professors (Bühlmann et al. 2018) and through research collaborations (Larivière et al. 2010; Gingras 2012). At the departmental level, social capital can be acquired through institutional affiliations during the career. Since, as stated before, international experiences seem to situate an individual closer to the autonomous pole of the scientific field, having been related to researchers in other countries also constitutes a form of intra-disciplinary social capital and a sign of belonging to a transnational scientific community (Bühlmann et al. 2013). In particular, stays at US departments lead to a large volume of important scientific resources in economics (Fourcade 2006). Finally, at the scientific production level, citations create a (more or less loose) directed tie between researchers (Kaplan 1965). If a scientist's work is cited, it denotes some sort of recognition among peers which can be activated and facilitates the creation of a more bonding connection (or not). Moreover, the works cited are published in a certain type of medium (i.e. scientific reviews, book collections, etc.). Being published in an "international" journal, for example, denotes the belonging to particular invisible colleges (Crane 1969), where one is able to gain certain scientific dispositions (i.e. scientific practices and know-how), which allowed this type of publication.

Extra-disciplinary social capital can be acquired through similar channels outside the disciplinary field of economics. At the institutional level, it can be obtained by sitting on more or less powerful boards and being tied to elites from different sectors of society (Mills 1956). In academia, social capital relates to executive boards of important (transdisciplinary) academic organisations or universities (Bourdieu 1988). Outside academia, positions occupied in the higher state administration, the parliament or the board of large companies allow individuals to develop strong ties to political and economic powers (Rossier et al. 2017; Larsen \& Ellersgaard 2018). At the inter-personal level, the supervision of the doctorate of future administrative, political and economic elites is another very strong tie to groups coming from outside the discipline and to the field of power. At the departmental level, having links to the same (Swiss) department, where some individuals have remained for most of their career, favours the insertion within a local community, which is often related to external logics (Wagner 2010). Consequently, individuals with local profile will tend to own extra-disciplinary forms of social capital.

In this chapter, we investigate the structure of social capital within the field of economists and its historical and institutional dynamics, paying particular attention to the relative importance of intra- and extra-disciplinary networks.

\section{Research strategy and methods}

\subsection{Data}

Our data stem from a historical database on Swiss elites ${ }^{6}$ and were collected as part of the research project "Academic Elites in Switzerland 1910-2000: 
Between Autonomy and Power". ${ }^{7}$ Our empirical analyses rely upon all the associate and full professors in economics (including financial economics) at all the ten Swiss universities and the two federal institutes of technology between the dates of 1980 and $2000(n=200)$. The choice of these dates allows us to study our object historically, but without focusing on a too-long time period which would prevent us from having comparable indicators. We stop at the date of 2000 in order to have rather complete biographical information on these professors' careers (the youngest professor of the group was 50 years old when data were collected in 2015). The names of the professors were collected using Swiss university directories (Annuaires des universités suisses) published yearly, which contain the complete list of the Swiss academic personnel at that time, as well as activity reports from the 12 universities. We then collected biographical information on these professors on the basis of diverse sources, such as the Swiss Historical Dictionary, the Who's Who in Switzerland, several university anniversary monographs, databases and other material provided by university archives, university activity reports, newspaper archives, online curricula, doctoral dissertations, the website moneyhouse.ch for the commerce register of Swiss companies and the "P3" database of the Swiss National Science Foundation for the funding of research from this institution.

\subsection{Methods: MCA and CSA}

In a first step, to visualise how forms of social capital vary between the 200 economics professors, we conduct a multiple correspondence analysis. MCA is a multivariate geometrical method aiming at reducing the complexity among a large set of categorical variables. It allows us to visualise this information based on the logic of several dimensions (or axes) of opposition between active (in the sense that they construct "actively" the space) variables. The first axis represents the most dominant opposition of resources and profiles, the second axis the second most dominant, etc. The closer individuals are in the space, the more they tend to share a common profile. Conversely, the closer the modalities of variables (i.e. resources) are situated in the space, the larger is the group of individuals who tend to share them. A set of illustrative variables, which do not contribute to construct the space, can be projected. Modalities and variables with a contribution above the average contribution are emphasised in the interpretation of the axes. Various measures of the part of the explained variance ("inertia") are projected onto an axis. Since these rates are usually low, they are recalculated in modified rates to better appreciate the importance of the first axes. Generally, we retain the number of axes, which represent at least $80 \%$ of the cumulated modified rates (Hjellbrekke 2018; Le Roux \& Rouanet 2010).

In a second empirical step, to grasp the historical evolution of the capitals among the field, we propose to use class specific MCA (CSA). After having separated the space among a certain number of sub-clouds based on illustrative variables (here, each year of professorship between 1980 and 2000), CSA searches for new axes within the given sub-clouds, while keeping the distances between individuals from the initial space. Thanks to that technique, we are 
able to measure the degree of similarity between individuals in every sub-cloud and in the whole space. The principal axes of the sub-clouds of individuals are compared to the initial axes. To assess their association, the cosines of the angle between the "old" and the "new" axes are recalculated in a standardised correlation coefficient between -1 and 1 (Hjellbrekke \& Korsnes 2016). By comparing the axes of each year to the axes of the whole space, we are able to assess historical evolutions within the field of economists. Our analyses are realised through the $R$ package soc.ca (Larsen et al. 2016).

\subsection{Indicators of social capital}

In this part, we specify the indicators we use as active variables in our MCA in order to focus on the forms of social capital described earlier. We also specify our illustrative variables. ${ }^{8}$

We measure intra-disciplinary social capital with the following indicators:

- Scientific institutional positions, through executive affiliations within scientific and disciplinary hierarchies, are considered by being a member of the executive board of the Swiss Society of Economics and Statistics, the main disciplinary association in Switzerland, and through department dean positions.

- Scientific inter-personal networks are twofold. First, to study the particular ties of professors to other (economics) university professors, which can be considered as the "elites" of the academic field, we investigate social capital through $\mathrm{PhD}$ supervision, by the number of $\mathrm{PhD}$ student members of the Swiss academic elites (university professors) and the number of PhD "brother"/ "sister" members of the academic elites. Second, we focus on links through research projects funded by the Swiss National Science Foundation (SNSF), the main public provider of scientific funding. Researchers can apply (as sole applicant or as co-applicants) for funding and receive money to conduct research during a given period of time (usually between one and four years). We are interested in their degree in scientific collaborations, i.e. their total number of co-applicants, and the number of years of scientific collaborations, i.e. the total number of years they have been involved in a project with at least one co-applicant. ${ }^{10}$

- For international departmental networks, we indicate if they have been involved, first, in an at least one-year stay outside Switzerland, and, second, in the US.

- Finally, to consider social capital through scientific production, we focus on the number of citations of the 10 most cited publications in the Web of Science. The Web of Science, run by Clarivate Analytics, compiles the citations since the year 1900 of around 12000 (mostly English-speaking) journals considered as the most "important" for each discipline. This indicator constitutes a good measure for prestige and recognition at the international (or at least Anglo-American) level, and for involvement in transnational scientific networks. 
We focus on extra-disciplinary social capital with the following indicators:

- Academic institutional positions are measured through membership in boards of important academic organisations (i.e. science "mandarins"), which encompass several disciplines, i.e. the social sciences and humanities and all the disciplines. We retain the following positions: member of the two leading organs of the Swiss National Science Foundation, the executive committee of the University Teachers Association, the Academy of Humanities and Social Sciences, the Commission for Technology and Innovation, and the Swiss Science Council. We also retain university vice-chancellors.

- Economic institutional positions are measured by three indicators: through economic elite positions, defined as CEOs or non-executive board members of the 110 largest Swiss companies, or executive committee member of the major business interest groups; through membership in the executive board of a firm; and in the non-executive board of a firm (no matter the size, total turnover, or the market capitalisation).

- State institutional positions relate to political or administrative elite positions. Political elites are members of the federal government and the federal parliament. Administrative elites are the governing board members of the Swiss central bank or heads of a federal office. Aside from these influential political positions, we also take into account members of federal expert committees, which are institutionalised expert groups whose main task is to advise the federal government and administration.

- Administrative, political and economic inter-personal networks, i.e. their links to economic, political and administrative elites, are again measured through $\mathrm{PhD}$ supervision: number of PhD student members of the Swiss extra-academic elites (according to the same definition as before) and number of PhD "brother" / "sister" members of the extra-academic elites.

- Finally, local departmental networks are measured through a process of local reproduction, by linking the university where professors obtained their doctorate and the university where they were appointed professors. If a professor teaches in the same university where he or she obtained his/her $\mathrm{PhD}$, it shows a particular local involvement.

Aside from these diverse forms of social capital, in order to work on subgroups based on time-periods, we project variables regarding the 21 years between 1980 and 2000 as illustrative variables to have each time a subgroup of people who were professors during a particular year. ${ }^{11}$

\section{The structure of social capital in economics}

We proceed to the analysis of the structure of social capital in the Swiss field of economists. In a first empirical part, we uncover the overall structure of the diverse forms of social capital by identifying dimensions of opposition among resources through MCA. In a second part, we test the evolution of this structure between 1980 and 2000 through CSA. 


\section{Thierry Rossier and Pierre Benz}

\subsection{External and internal social capitals}

In this part, we proceed to a multiple correspondence analysis to highlight the principal oppositions within the structure of social capital of economics professors between 1980 and $2000(n=200)$. The analysis relies on 19 active variables (47 active modalities), which measure different forms of social capital (see Table 13.1 for the contributions and frequencies of the active variables and modalities; the ones contributing to each axis above the average contribution are highlighted in grey). The first two axes account for $81 \%$ of the cumulated

Table 13.1 Contributions and frequencies of the active variables and modalities

\begin{tabular}{|c|c|c|c|c|c|c|}
\hline Form of social capital & Dimension & Variable & Modality & Dim. 1 & Dim. 2 & Freq. \\
\hline \multirow{30}{*}{$\begin{array}{l}\text { Intra-disciplinary } \\
\text { social capital }\end{array}$} & \multirow{6}{*}{$\begin{array}{l}\text { Scientific } \\
\text { institutional } \\
\text { positions }\end{array}$} & \multirow{3}{*}{$\begin{array}{l}\text { Board member of Swiss } \\
\text { Society of Economics and } \\
\text { Statistics }\end{array}$} & No & 0.6 & 2.2 & 158 \\
\hline & & & Yes & 2.2 & 8.1 & 42 \\
\hline & & & Total & 2.8 & 10.3 & 200 \\
\hline & & \multirow[t]{3}{*}{ Department dean } & No & 0.9 & 1.4 & 124 \\
\hline & & & Yes & 1.4 & 2.2 & 76 \\
\hline & & & Total & 2.3 & 3.6 & 200 \\
\hline & \multirow{18}{*}{$\begin{array}{l}\text { Scientific inter- } \\
\text { personal } \\
\text { networks }\end{array}$} & \multirow{4}{*}{$\begin{array}{l}\text { PhD student member of } \\
\text { academic elites }\end{array}$} & 0 & 1.2 & 1.0 & 123 \\
\hline & & & $1-2$ & 0.7 & 0.0 & 58 \\
\hline & & & $3+$ & 1.7 & 5.1 & 19 \\
\hline & & & Total & 3.6 & 6.1 & 200 \\
\hline & & \multirow{4}{*}{$\begin{array}{l}\mathrm{PhD} \text { "brother"/"sister" } \\
\text { member of academic elites }\end{array}$} & 0 & 6.2 & 1.6 & 93 \\
\hline & & & $1-3$ & 2.6 & 1.8 & 88 \\
\hline & & & $4+$ & 4.0 & 0.0 & 19 \\
\hline & & & Total & 12.8 & 3.4 & 200 \\
\hline & & \multirow{5}{*}{$\begin{array}{l}\text { Degree in scientific } \\
\text { collaboration (SNSF) }\end{array}$} & 0 & 1.6 & 5.0 & 79 \\
\hline & & & $1-5$ & 0.0 & 0.1 & 78 \\
\hline & & & $6-10$ & 2.2 & 9.3 & 29 \\
\hline & & & $11+$ & 0.2 & 2.8 & 14 \\
\hline & & & Total & 4.0 & 17.2 & 200 \\
\hline & & \multirow{5}{*}{$\begin{array}{l}\text { Years of research } \\
\text { collaboration (SNSF) }\end{array}$} & 0 & 1.7 & 4.6 & 104 \\
\hline & & & $1-5$ & 0.0 & 0.3 & 46 \\
\hline & & & $6-10$ & 1.8 & 2.6 & 36 \\
\hline & & & $11+$ & 1.1 & 5.5 & 14 \\
\hline & & & Total & 4.6 & 13.0 & 200 \\
\hline & \multirow{6}{*}{$\begin{array}{l}\text { International } \\
\text { departmental } \\
\text { networks }\end{array}$} & \multirow[t]{3}{*}{ Stay in other country } & No & 4.1 & 10.3 & 47 \\
\hline & & & Yes & 1.3 & 3.2 & 153 \\
\hline & & & Total & 5.4 & 13.5 & 200 \\
\hline & & \multirow[t]{3}{*}{ Stay in the US } & No & 0.1 & 3.9 & 118 \\
\hline & & & Yes & 0.2 & 5.7 & 82 \\
\hline & & & Total & 0.3 & 9.6 & 200 \\
\hline
\end{tabular}




\begin{tabular}{|c|c|c|c|c|c|c|}
\hline Form of social capital & Dimension & Variable & Modality & Dim. 1 & Dim. 2 & Freq. \\
\hline \multirow{11}{*}{$\begin{array}{l}\text { Extra-disciplinary } \\
\text { social capital }\end{array}$} & \multirow{5}{*}{$\begin{array}{l}\text { Scientific } \\
\text { production }\end{array}$} & \multirow{5}{*}{$\begin{array}{l}\text { Number of citations in Web } \\
\text { of Science (10 most cited } \\
\text { publications) }\end{array}$} & 0 & 1.6 & 6.9 & 66 \\
\hline & & & $1-200$ & 0.0 & 0.3 & 91 \\
\hline & & & $201-500$ & 0.9 & 2.2 & 28 \\
\hline & & & $501+$ & 0.7 & 4.1 & 15 \\
\hline & & & Total & 3.2 & 13.5 & 200 \\
\hline & \multirow{6}{*}{$\begin{array}{l}\text { Academic } \\
\text { institutional } \\
\text { positions }\end{array}$} & \multirow{3}{*}{$\begin{array}{l}\text { Academic organisation board } \\
\text { (science "mandarins") }\end{array}$} & No & 0.3 & 0.1 & 184 \\
\hline & & & Yes & 3.7 & 1.4 & 16 \\
\hline & & & Total & 4.0 & 1.5 & 200 \\
\hline & & \multirow[t]{3}{*}{ University vice-chancellor } & No & 0.3 & 0.1 & 187 \\
\hline & & & Yes & 4.6 & 0.9 & 13 \\
\hline & & & Total & 4.9 & 1.0 & 200 \\
\hline & \multirow{9}{*}{$\begin{array}{l}\text { Economic } \\
\text { institutional } \\
\text { positions }\end{array}$} & \multirow[t]{3}{*}{ Economic elite members } & No & 0.4 & 0.0 & 186 \\
\hline & & & Yes & 4.7 & 0.1 & 14 \\
\hline & & & Total & 5.1 & 0.1 & 200 \\
\hline & & \multirow[t]{3}{*}{ Executive board of company } & No & 0.2 & 0.1 & 172 \\
\hline & & & Yes & 1.2 & 0.3 & 28 \\
\hline & & & Total & 1.4 & 0.4 & 200 \\
\hline & & \multirow{3}{*}{$\begin{array}{l}\text { Non-executive board of } \\
\text { company }\end{array}$} & No & 1.5 & 0.4 & 141 \\
\hline & & & Yes & 3.6 & 0.9 & 59 \\
\hline & & & Total & 5.1 & 1.3 & 200 \\
\hline & \multirow{6}{*}{$\begin{array}{l}\text { State } \\
\text { institutional } \\
\text { positions }\end{array}$} & \multirow{3}{*}{$\begin{array}{l}\text { Political or administrative } \\
\text { elite members }\end{array}$} & No & 0.1 & 0.0 & 191 \\
\hline & & & Yes & 2.2 & 0.0 & 9 \\
\hline & & & Total & 2.3 & 0.0 & 200 \\
\hline & & \multirow[t]{3}{*}{ Expert committee member } & No & 3.0 & 0.0 & 137 \\
\hline & & & Yes & 6.6 & 0.1 & 63 \\
\hline & & & Total & 9.6 & 0.1 & 200 \\
\hline & \multirow{7}{*}{$\begin{array}{l}\text { Administrative, } \\
\text { political and } \\
\text { economic } \\
\text { inter-personal } \\
\text { networks }\end{array}$} & \multirow{3}{*}{$\begin{array}{l}\text { PhD student member of } \\
\text { extra-academic elites }\end{array}$} & 0 & 1.2 & 0.0 & 169 \\
\hline & & & $1+$ & 6.3 & 0.0 & 31 \\
\hline & & & Total & 7.5 & 0.0 & 200 \\
\hline & & \multirow{4}{*}{$\begin{array}{l}\text { PhD "brother"/“sister" } \\
\text { member of extra-academic } \\
\text { elites }\end{array}$} & 0 & 3.2 & 0.2 & 142 \\
\hline & & & $1-3$ & 4.6 & 0.3 & 42 \\
\hline & & & $4+$ & 3.3 & 0.1 & 16 \\
\hline & & & Total & 11.1 & 0.6 & 200 \\
\hline & \multirow{3}{*}{$\begin{array}{l}\text { Local } \\
\text { departmental } \\
\text { networks }\end{array}$} & \multirow{3}{*}{$\begin{array}{l}\text { Local reproduction (professor } \\
\text { in university of } \mathrm{PhD} \text { ) }\end{array}$} & No & 3.8 & 1.9 & 121 \\
\hline & & & Yes & 5.9 & 3.0 & 79 \\
\hline & & & Total & 9.7 & 4.9 & 200 \\
\hline
\end{tabular}

modified rates (Table 13.2), therefore we only retain those for our analyses. Figure 13.1 displays the cloud of modalities and Figure 13.2 the cloud of individuals. We see a concentration of individuals on the lower and left parts, while the cloud is sparser in its upper and right parts. This less dense zone 
236 Thierry Rossier and Pierre Benz

Table 13.2 Inertia rates of the 11 first axes of the MCA

\begin{tabular}{llllllllllllll}
\hline Axis & 1 & 2 & 3 & 4 & 5 & 6 & 7 & 8 & 9 & 10 & 11 \\
\hline Eigenvalue & 0.18 & 0.12 & 0.10 & 0.09 & 0.08 & 0.07 & 0.07 & 0.06 & 0.06 & 0.06 & 0.05 \\
Variance (\%) & 12.4 & 8.2 & 6.5 & 6.0 & 5.6 & 5.0 & 4.7 & 4.3 & 4.2 & 3.9 & 3.7 \\
$\begin{array}{c}\text { Modified } \\
\quad\end{array}$ & 63.3 & 17.7 & 7.2 & 5.0 & 3.2 & 1.6 & 1.1 & 0.5 & 0.3 & 0.1 & 0.0 \\
$\begin{array}{c}\text { rates (\%) } \\
\begin{array}{c}\text { umulated } \\
\text { modified }\end{array}\end{array}$ & 63.3 & 81.0 & 88.2 & 93.2 & 96.4 & 98.0 & 99.1 & 99.6 & 99.9 & 100.0 & 100.0 \\
$\quad$ rates (\%) & & & & & & & & & & & \\
\hline
\end{tabular}

Axes 1-2

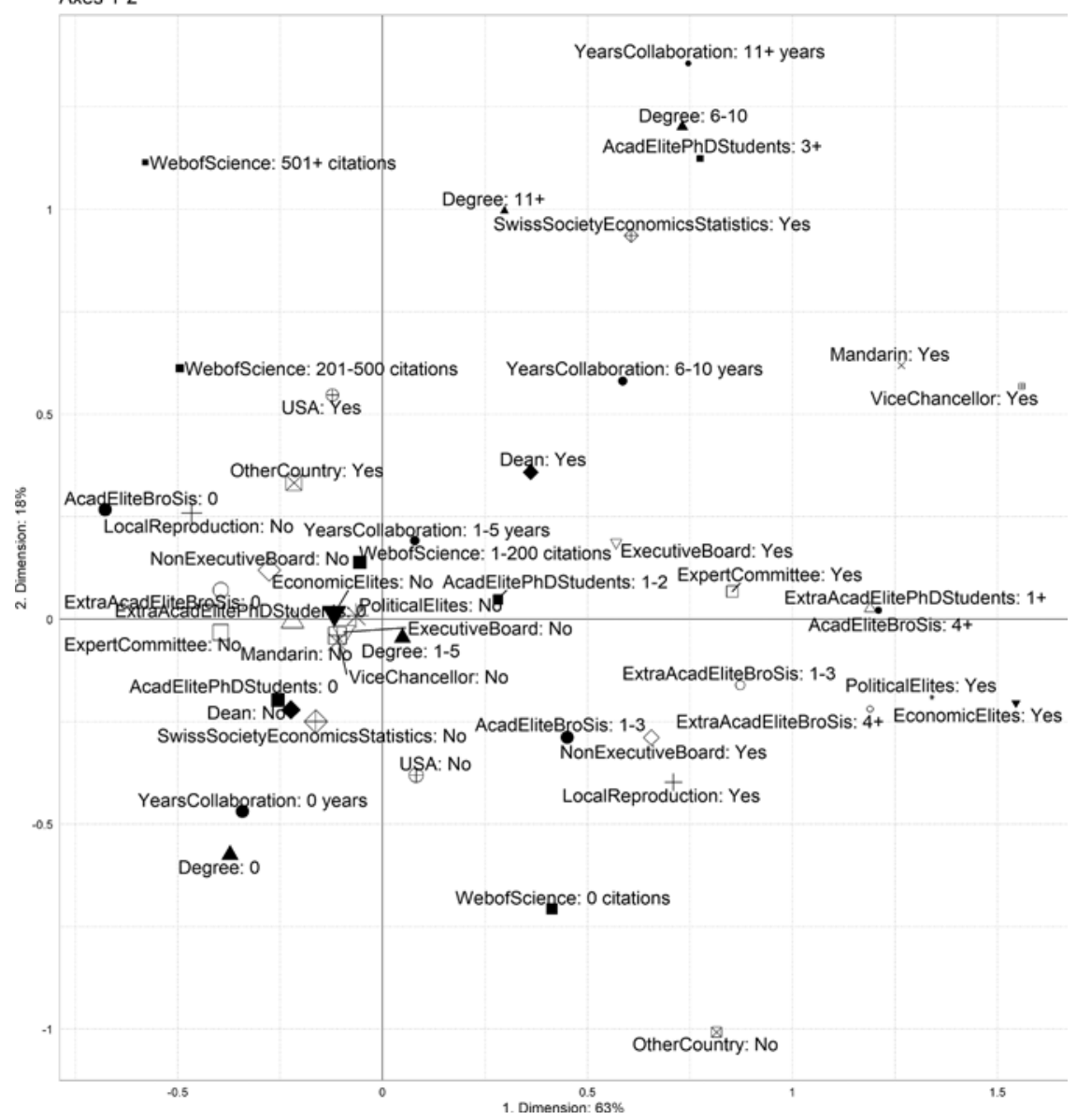

Figure 13.1 Axes 1 and 2. Cloud of modalities 


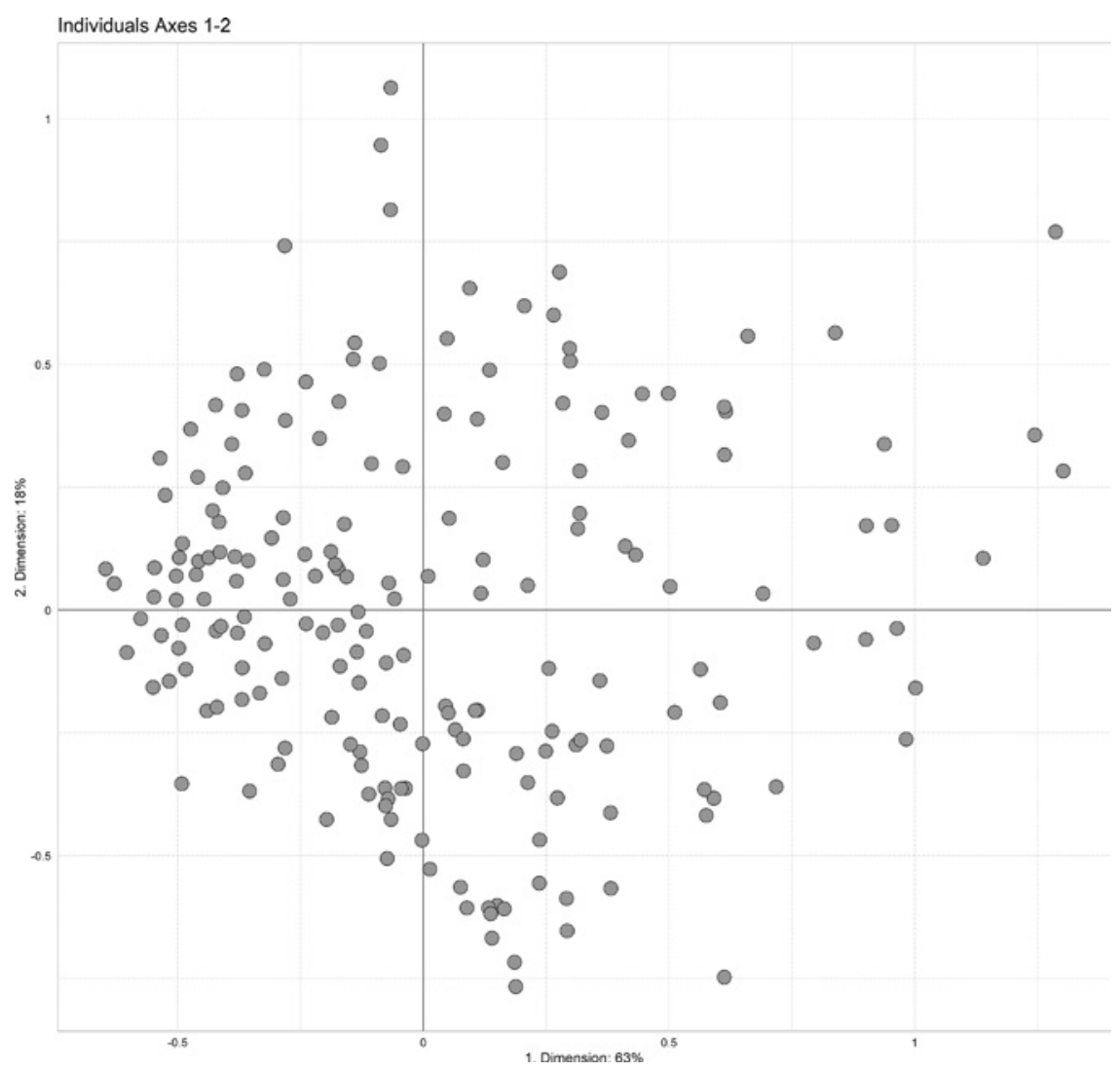

Figure 13.2 Axes 1 and 2. Cloud of individuals

corresponds to a small group of individuals with powerful resources situated on the right pole of Axis 1 and the upper pole of Axis 2, while the majority of individuals detains less important resources in the space.

Axis 1 represents $63.3 \%$ of the adjusted inertia rates. Six variables contribute to this factor above the contributions average (i.e. 5.3\%), for a total of 56.1\%: PhD "brother" / "sister" members of the academic elites (12.8\%), PhD "brother" /"sister" members of the extra-academic elites (11.1\%), local reproduction (9.7\%), expert committee (9.6\%), PhD students members of extraacademic elites (7.5\%) and stay in other country (5.4\%). Nineteen modalities contribute to this axis above the contributions average (i.e. 2.1\%), for a total of $76.8 \%$. On the negative coordinates (west of the graph), we find PhD "brother" " "sister" members of the academic elites: 0 (6.2\%), local reproduction: no (3.8\%), PhD "brother" / "sister" members of the extra-academic elites: $0(3.2 \%)$ and expert committee: no (3.0\%). On the positive coordinates (east of 
the graph), we find expert committee: yes (6.6\%), PhD students members of the extra-academic elites: $1+(6.3 \%)$, local reproduction: yes $(5.9 \%)$, economic elite: yes (4.7\%), vice-chancellor: yes (4.6\%), $\mathrm{PhD}$ "brother"/"sister" members of the extra-academic elites: 1-3 (4.6\%), stay in other country: no (4.1\%), $\mathrm{PhD}$ "brother" / "sister" members of the academic elites: 4+ (4.0\%), academic organisation: yes (3.7\%), non-executive board of company: yes (3.6\%), $\mathrm{PhD}$ "brother"/"sister" members of the extra-academic elites: $4+(3.3 \%), \mathrm{PhD}$ "brother"/"sister" members of the academic elites: 1-3 (2.6\%), political or administrative elite: yes (2.2\%), Swiss Society of Economics and Statistics: yes $(2.2 \%)$ and degree in scientific collaborations: $6-10(2.2 \%)$.

The first axis is structured by the volume of social capital, but of a particular kind. On the one hand, we see economists with extra-academic affiliations (members of an expert committee for the Swiss federal administration, member of the Swiss political and economic elites, member of the non-executive board of a company) and large external networks (they have the same supervisor as a large number of other political, administrative and economic elites, and have themselves supervised the doctorate of such elite members). At the same time, they have an important influence in the higher circles of academia outside their discipline (they have occupied the position of vice-chancellor of a university and have been a member of the directing board of important interdisciplinary academic organisations, such as the SNSF) and have a certain amount of academic networks, having the same supervisor as a large number of other university professors (but they have not supervised the $\mathrm{PhD}$ of future professors themselves). ${ }^{12}$ Finally, they are involved in local circles (having obtained their $\mathrm{PhD}$ in the same university in which they are teaching) and detain no tie outside Switzerland. Opposed to these individuals who are endowed with a large amount of mundane networks, largely outside their discipline, ${ }^{13}$ we see, on the other hand, professors of economics without academic and extra-academic networks in the form of having the same supervisor of other elite members, without local social capital, and without political affiliations, in the form of membership in an expert committee. In summary, this factor, which is by far the most important in the space, corresponds to an axis of volume of extradisciplinary social capital (in its academic, political and economic forms, mostly organised at the local level, and without international ties), divided between those who own this form of capital and those who do not.

Powerful individuals detaining very important external social capital are situated on the right pole of this first axis (see Figure 13.3), such as Joseph Deiss (professor of economic policy in Fribourg), a member of the federal parliament who became part of the Federal Council (the federal government) between 1999 and 2006. We can also mention Niklaus Blattner (professor of labour market and economic industry in Basel) who was the executive secretary of the Swiss Bankers Association, one the most important business interest groups, and member of the governing board of the Swiss central bank, and Gaston Gaudard (professor of international and regional economics in Fribourg and Lausanne) who was vice-chancellor of the University of Fribourg, member of one of the two leading boards of the SNSF and member of the board of 


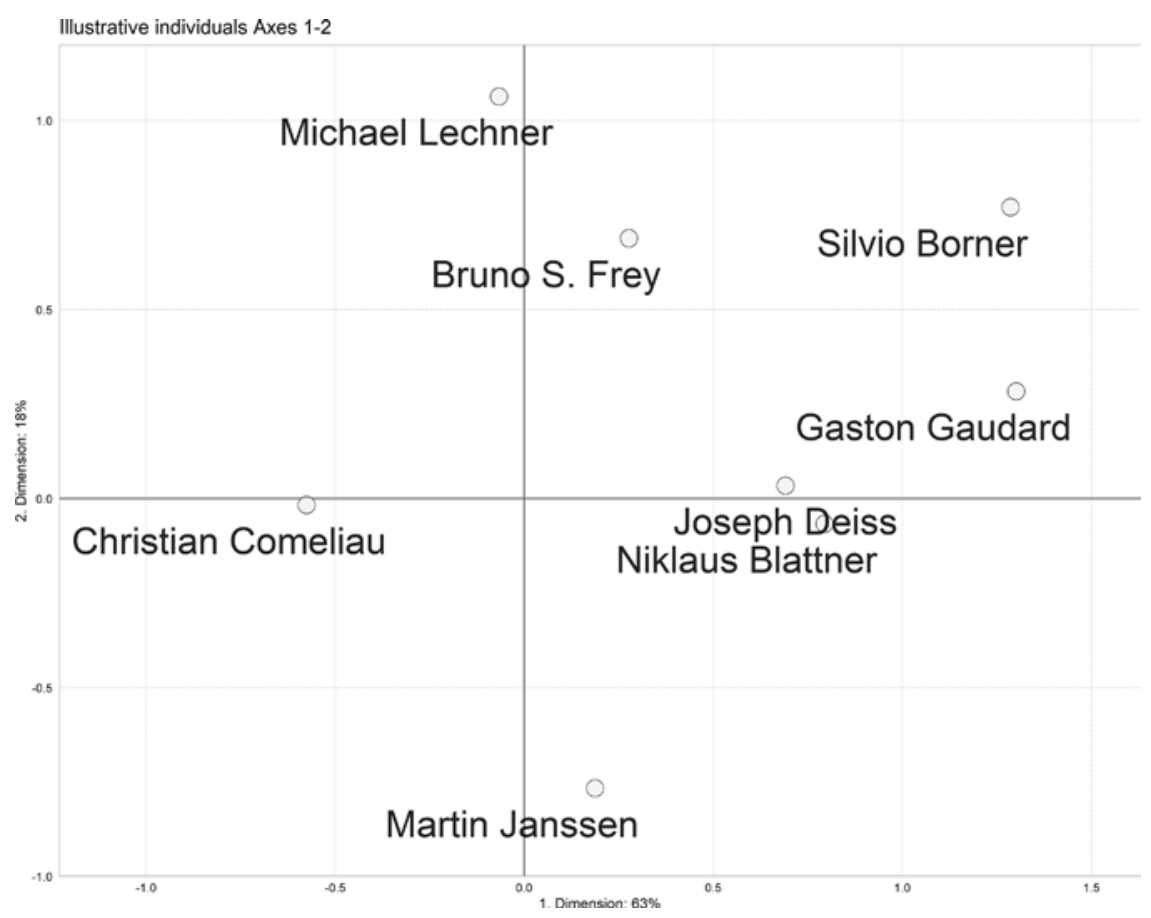

Figure 13.3 Axes 1 and 2. Illustrative individuals.

the Sociéte de banque suisse, one of the country's three major banks at the time. On the other pole (left side of the axis), we see individuals with few network resources in Switzerland, such as the Belgian and French professor Christian Comeliau who taught economic development in Geneva, after having occupied teaching positions in Louvain, Kinshasa and Paris. Comeliau detained no important resources in Swiss extra-academic circles whatsoever.

Axis 2 only accounts for $17.7 \%$ of the cumulated modified rates. The opposition represented through Axis 1 is therefore 3.5 times more important than the one through Axis 2 . Seven variables contribute to this axis above average (for a total of 83.2\%): degree in scientific collaborations (17.2\%), citations in Web of Science (13.5\%), stay in other country $(13.5 \%)$, years of research collaborations (13.0\%), board of Swiss Society of Economics and Statistics (10.3\%), stay in the US (9.6\%), and $\mathrm{PhD}$ students members of academic elites (6.1\%). Eighteen modalities contribute to this factor above average (for a total of $86.7 \%$ ). On the negative coordinates (south of the graph), we find stay in other country: no $(10.3 \%)$, citations in Web of Science: $0(6.9 \%)$, degree in scientific collaborations: $0(5.0 \%)$, years of research collaborations: 0 (4.6\%), stay in the US: no (3.9\%), local reproduction: yes (3.0\%) and Swiss Society of Economics and 
Statistics: no $(2.2 \%)$. On the positive coordinates (north of the graph), we find: degree in scientific collaborations: 6-10 (9.3\%), Swiss Society of Economics and Statistics: yes $(8.1 \%)$, stay in the US: yes $(5.7 \%)$, years of research collaborations: $11+(5.5 \%), \mathrm{PhD}$ students members of academic elites: $3+(5.1 \%)$, citations in Web of Science: $501+(4.1 \%)$, stay in other country: yes (3.2\%), degree in scientific collaborations: $11+(2.8 \%)$, years of research collaborations: $6-10$ (2.6\%), dean: yes (2.2\%) and citations in Web of Science: 201-500 (2.2\%).

This second axis displays another opposition. It shows, on one side, economics professors owning a large amount of intra-disciplinary social capital: members of the board of the disciplinary association, university department deans, a great number of co-applicants in the SNSF network, a large number of collaboration years and a lot of citations in the Web of Science. These networks are organised at the national (SNSF) and international (Web of Science) levels at the same time. They also own international social capital, having stayed for scientific research for at least one year outside Switzerland, in particular in the USA. They detain a large share of academic networks, having supervised the doctorate of future Swiss economics professors. Regarding "elite" PhD networks, the division is clear and the powers associated with both dimensions of opposition in the space have to be differentiated: Individuals with a large amount of capitals associated with Axis 1 have the same supervisor as other academic and extra-academic elite members and have supervised extra-academic elites only, meanwhile individuals with a lot of resources coming from the second dimension of the space solely supervise the $\mathrm{PhD}$ of academic elites. On the other side, we see economics professors without scientific networks (no citations, no collaborations, no positions in the board of the association), without international networks, but in the process of local power reproduction (doctorate in the teaching university). This dimension summarises then a volume of intra-disciplinary social capital (organised at the national and international levels), divided again between those who detain it and those who do not (but do own local social capital).

On the upper pole of Axis 2, we see individuals with powerful scientific and international networks such as the "superstar" Bruno S. Frey (professor of theoretical and practical economics in Basel, Konstanz, Zurich and Warwick) who is one of the most cited European economists (more than 5000 citations of his ten most cited publications in Web of Science) and collaborated in numerous research projects; or Michael Lechner (professor of econometrics in St. Gallen, after occupying positions in Harvard and Mannheim), member of the board of the Swiss Society of Economics and Statistics and dean in St. Gallen, with a fair record of citations (more than 200) and numerous research collaborations. On the lower pole, we observe individuals with a more local profile and no scientific network resources whatsoever, such as Martin Janssen, who did his $\mathrm{PhD}$ in Zurich before becoming professor of financial economics in the same university and sat in numerous company boards, but with no insertion in intradisciplinary networks whatsoever. 
In summary, our results show how the space is structured according to two dimensions: the first displays the volume of extra-disciplinary social capital and the second of intra-disciplinary social capital. Both those dimensions are structured according to the overall volume of resources, dividing the dominant, who detain a large amount of social capital, and the dominated, who do not. Particularly dominant economists are to be found in the north-east quadrant of the space where the volume of both forms of social capital is high, such as Silvio Borner (professor of economic policy in St. Gallen and Basel), a wellknown expert for the federal administration, dean in both universities, member of the board of the disciplinary association and of the insurance company Helvetia (one of the most important in the country). Borner, who is one of the most influential actors in the field, became in the 1990 s very active within the so-called neoliberal coalition (Mach 2002), which advocated drastic policy reforms that would eventually lead to the liberalisation of the Swiss economy.

It is to be noted that the first opposition has much more weight in the space than the second $(63.3 \%$ of the inertia rates against $17.7 \%)$. Economics is thus a much more heteronomous discipline than economists would say it is. Indeed, our results show the importance of external logics, whether in the form of political, economic or (transdisciplinary) academic networks. Nonetheless, we can still wonder if, despite this overall trend, there has been some historical changes regarding the importance of these two dimensions. Some could even hypothesise a reversing movement in the importance of both these logics during the very recent period. We investigate the historical evolution of this structure between 1980 and 2000 .

\subsection{Importance of heteronomous networks during the 1980-2000 period}

In this second part, we assess the importance of the two main dimensions of social capital (and thus the robustness of our analyses) during the historical period on which we focus. To do so, we proceed to a class-specific MCA (CSA) on each group of professors separated by year (i.e. whether they occupy a professor position at a Swiss university in each given year). Figure 13.3 shows the association (calculated by standardising the cosine) between the first axis of the MCA for the entire group, and the first axis of the CSA for each year between 1980 and 2000 (i.e. "Dimension 1"), and between the second axis of the MCA and the second axis of the CSA for each group respectively (i.e. "Dimension 2"). By doing so, we are able to see whether there are variations across time in the intensity of both dimensions identified in the previous part, or if the structure stays stable during the whole period, and thus social capital reproduces itself across time.

We observe that for the first axis, the association between Axis 1 of the MCA and of the CSAs by year is very high and does not vary a lot (correlation coefficients: $\mu=0.97$, sd $=0.01$ ). Therefore, the first dimension, related to the volume of extra-disciplinary social capital, remains particularly stable. 


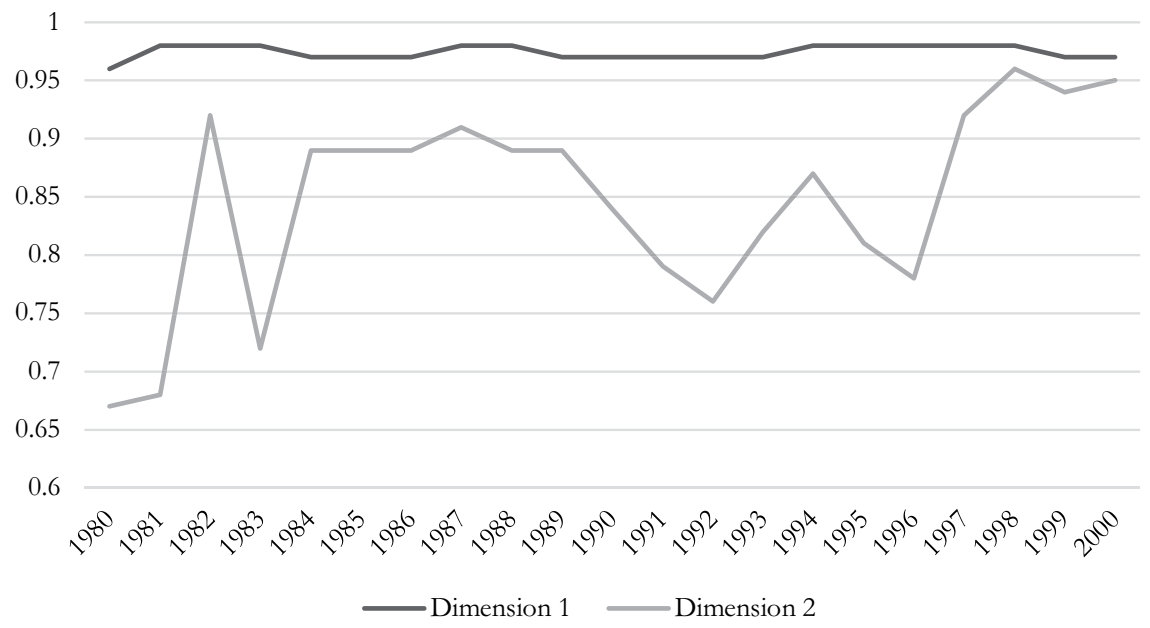

Figure 13.4 Correlation coefficients (absolute values) between axes of the MCA and the CSA by year

Heteronomous networks are, for the whole period, the most important source of distinction in the field of economists. For the associations between Axis 2 of the MCA and of the CSAs, a larger variance of the correlation coefficients can be observed $(\mu=0.85$, sd $=0.09)$. By calculating the slope of the line which represents the evolution of the association among these axes, we observe, despite some variations, a relative (but significant) increase in importance of the association between the second axis of the MCA and of the CSAs for each year between 1980 and 2000. ${ }^{14}$ Intra-disciplinary social capital has more weight in the recent period. This increase could explain, to some extent, the belief in the autonomy of the field. However, this process cannot hide the fact that the structure of social capital remains very stable during the whole period, and, consequently, the main logics of structuration of the field do not lose in importance. Extra-disciplinary social capital (such as sitting in academic, expert or company boards) has proven to be of an important value in economics for the whole period. ${ }^{15}$

\section{Conclusions}

The main aim of this chapter was to focus on the structure of social capital within the Swiss field of economists by relying on the sociological profile of 200 economics professors between 1980 and 2000. In a first part, we showed that the space was structured according to two dimensions. The main one was organised around the volume of extra-disciplinary social capital through academic, economic and political affiliations, as well as extra-academic and 
local networks. The secondary opposition was organised around the volume of intra-disciplinary social capital: scientific affiliations, personal scientific and international ties, and networks of citations. In economics heteronomous logics are the most prevalent in order to detain power defined as the ability to use one's own personal network composed of the collective resources owned by all the other individuals a professor is directly connected to. This type of power mostly consists in being able to influence the outcome of public and academic policy or the economy, therefore primarily outside the discipline. Nonetheless, a secondary type of power can be identified, consisting in being able to influence other economists with one's own writings and research, thus within the discipline. In a second part, we showed that the importance of extradisciplinary social capital remained stable across the whole period. At the same time, intra-disciplinary social capital varied more and experienced a slight, but significant, increase in importance between 1980 and 2000. Despite this evolution, mundane networks constitute the main form of opposition for the whole period, which stresses the porosity of the field to external logics.

These network affiliations and resources configurations also have repercussions outside of the positional structure of the field. They influence position-takings in economics, measured through theoretical and methodological preferences, as well as research domains. Based on qualitative insights we have developed in the previous parts through illustrative profiles of professors, we have observed different teaching and research specialisation. On the first axis, economic, political and administrative elites as well as academic "mandarins" (right of the axis) teach very "practical" topics, such as economic, industry or labour market policy, while on the pole of the have-nots (left side of the axis), research domains are less close to the state and economic powers (Christian Comeliau for example is a "heterodox" economist working on economic development). On the second axis, renowned scientists (top of the axis) use mathematical models and experimental and statistical methods, linked to "autonomous" practices in economics, and work on a variety of scientific objects (in his own words, Bruno S. Frey applies economics in "non-economic fields" $\left.{ }^{16}\right)$. On the bottom of the axis, the "scientific" have-nots work on more applied topics, such as finance. Network and capital configurations are critical in influencing how economics is defined and how scientific practice is done.

In this chapter, we have focused on structural, institutional and historical processes related to the forms of social capital in the field of economists. These networks of economists have to be situated in a wider context. Scholars have noted important transformations since Bourdieu's seminal work on the field of power in the 1970s-1980s (1996a). First, the boundaries among economic and cultural capital are much blurrier than before, because cultural capital accumulation is increasing at the economic pole of the field, and, second, neoliberalism has renewed oppositions by submitting politics and the higher civil service to the aims of the private companies (Denord \& Lagneau-Ymonet 2016: 46). The historical role of economists in this process must not be underestimated, since their scientific apparel and tools are particularly efficient in spreading the 
"economic belief" within the whole society (Lebaron 2000; Denord 2016). It is thus needed to explore the modalities and forms of networks of the economists in the field of power in order to unveil their role in the recent process of concentration of (economic and cultural) power within the hands of the economic fraction of the dominant class.

\section{Notes}

1 We would like to thank Philip Korom and Stephan Pühringer for their very relevant comments and their deep reading of a former version of this chapter, which greatly contributed to improve it.

2 "SSES Annual Congress 2017 - Marion Fourcade", www.youtube.com/watch?v=yR9Fe3cW9E (58:16-59:08).

3 We can find similar statements regarding the objectivity of economics at the very top of the discipline. Nobel Prize laureate Robert Schiller stated in an interview, "The Nobel Prize is designed to reward those who do not play tricks for [public and media] attention, and who, in their sincere pursuit of the truth, might otherwise be slighted", cited in Ötsch et al. (2018: 37).

4 A field is a more or less autonomous space, where individuals struggle for its specific capital, which enables them to occupy dominant positions (Bourdieu 1996b).

5 A capital is a form of powerful resources involved in systemic processes allowing their garnering (Savage et al. 2005; Bourdieu 1986).

6 The "Swiss Elite Database", developed by the Swiss Elite Observatory (www.unil.ch/ obelis/en/home.html), where elites are defined according to their position (Mills 1956). Elite members are the individuals occupying executive or top positions within the hierarchies of power institutions in several Swiss fields.

7 This project (100017_143202) was funded by the Swiss National Science Foundation and was supervised by Felix Bühlmann, André Mach and Thomas David.

8 To look all those variables summarised in a table (as well as their contributions to the first two axes of the MCA), see Table 13.1.

9 We name that way individuals with the same Doktorvater (i.e. Ph.D. supervisor) to mark the analogy with family ties.

10 To have comparable data among all the professors, we decided to measure this number of years before the age of 51, since the youngest professor was 50 during our data collection.

11 We will not address gendered considerations in this chapter because of lack of space. Women are under-represented within this group of professors: only eight women out of 200 professors. However, given the variety of profiles of these eight women, we were not able to observe a gendered differentiation between their social capital configurations and male professors' profile. A deeper research on women professors in economics is currently ongoing. Preliminary results can be found in Rossier (2019).

12 Given our empirical findings, it seems quite unexpectedly that having the same supervisors as other university professors belongs more to external logics rather than internal ones.

13 Two other modalities, which contribute above average to Axis 1, correspond more to disciplinary scientific networks and powers rather than to extra-disciplinary social capital: member of the board of the disciplinary Swiss Society of Economics and Statistics: yes, and number (degree) of collaborations in the scientific network funded by the SNSF: 6-10. To a certain extent, they are related to academic and external powers. Indeed, the disciplinary association is at the same time the scientific centre of the discipline, and the interface between economics and political powers (Jost 2016). The SNSF collaboration network mostly corresponds to a network motivated by scientific 
logics, but at the same time some "big" projects with a large amount of funding and coapplicants can follow a public agenda and be intricately related to political powers (Benninghoff \& Leresche 2003). Nonetheless, these modalities contribute both to the axis just above average $(=2.2 \%)$, contrary to their contribution to the second axis, which is very important.

14 The equation $\mathrm{y}=\mathrm{a} \star \mathrm{x}+\mathrm{b}$, where a corresponds to the slope: $\mathrm{y}=0.0066 \mathrm{x}+12.308$ $\left(\mathrm{R}^{2}=0.23\right)$.

15 It is to be noted that we do not have comparable data for the more recent period (2001-2020) on social capital, since economics professors appointed after that tend to have experienced shorter academic careers (and their Ph.D. students have not already had the time to be part of the elite). One could hypothesise that the importance of those two dimensions has reversed during the very recent period. However, given the historical stability of the prevalence of heteronomous networks in the field of economists, we can suppose that the structure of the field has not moved quickly in this direction since 2001.

16 Such as "happiness, politics. .., environment, family, conflict, history and art" (Bruno S. Frey's CV: www.bsfrey.ch/cv/EN_2019_CV_Bruno_Frey_Long.pdf).

\section{References}

Benninghoff, M., \& Leresche, J.-P. (2003). La recherche, affaire d'Etat. Enjeux et luttes d'une politique fédérale des sciences. Lausanne: PPUR.

Benz, P. (2019). Des sciences naturelles aux sciences de la vie. Changements et continuités des élites académiques de la biologie et de la chimie en Suisse au $\mathrm{XX}^{e}$ siècle. $\mathrm{PhD}$ dissertation, University of Lausanne.

Beyer, K., \& Pühringer, S. (2019). Divided We Stand? Professional Consensus and Political Conflict in Academic Economics. ICAE Working Paper Series (94).

Bourdieu, P. (1986). The Forms of Capital. In J. G. Richardson (Ed.), Handbook of Theory and Research for the Sociology of Education (pp. 241-258). New York: Greenwood.

Bourdieu, P. (1988). Homo Academicus. Palo Alto, CA: Stanford University Press.

Bourdieu, P. (1996a). The State Nobility: Elite Schools in the Field of Power. Cambridge: Polity Press; Oxford: Blackwell Publishers Ltd.

Bourdieu, P. (1996b). The Rules of Art: Genesis and Structure of the Literary Field. Palo Alto, CA: Stanford University Press

Bourdieu, P. (2004). Science of Science and Reflexivity. Chicago: The University of Chicago Press.

Bourdieu, P. (2005). The Social Structures of the Economy. Cambridge: Polity Press.

Bühlmann, F., Benz, P., Mach, A., \& Rossier, T. (2017). Mapping the Power of Law Professors: The Role of Scientific and Social Capital. Minerva: A Review of Science, Learning and Policy, 55(4), 509-531.

Bühlmann, F., David, T., \& Mach, A. (2012). Political and Economic Elites in Switzerland: Personal Interchange, Interactional Relations and Structural Homology. European Societies, 14(5), 727-754.

Bühlmann, F., David, T., \& Mach, A. (2013). Cosmopolitan Capital and the Internationalization of the Field of Business Elites: Evidence from the Swiss Case. Cultural Sociology, 7(2), 211-229.

Bühlmann, F., Rossier, T., \& Benz, P. (2018). The Elite Placement Power of Professors of Law and Economic Sciences. In O. Korsnes, J. Hjellbrekke, M. Savage, J. Heilbron, \& F. Bühlmann (Eds.), New Directions in Elite Studies (pp. 247-264). Oxford \& New York: Routledge. 
Crane, D. (1969). Social Structure in a Group of Scientists: A Test of the "invisible college" Hypothesis. American Sociological Review, 34(3), 335-352.

De Nooy, W. (2003). Fields and Networks: Correspondence Analysis and Social Network Analysis in the Framework of Field Theory. Poetics, 31(5-6), 305-327.

Denord, F. (2016). Le néo-libéralisme à la française. Histoire d'une idéologie politique. Marseille: Editions Agone.

Denord, F., Hjellbrekke, J., Korsnes, O., Lebaron, F., \& Le Roux, B. (2011). Social Capital in the Field of Power: The Case of Norway. The Sociological Review, 59(1), 86-108.

Denord, F., \& Lagneau-Ymonet, P. (2016). Le concert des puissants. Paris: Editions Raison d'agir.

Eloire, F. (2014). Qui se ressemble s'assemble? Homophilie sociale et effet multiplicateur: les mécanismes du capital social. Actes de la recherche en sciences sociales, 205, 104-119.

Eloire, F. (2018). The Bourdieusian Conception of Social Capital: A Methodological Reflection and Application. Forum for Social Economics, 47(3-4), 322-341.

Fourcade, M. (2006). The Construction of a Global Profession: The Transnationalization of Economics. American Journal of Sociology, 112(1), 145-194.

Fourcade, M. (2009). Economists and Societies: Discipline and Profession in the United States, Britain, and France, 1890s to 1990s. Princeton: Princeton University Press.

Fourcade, M. (2018). Economics: The View from Below. Swiss Journal of Economics and Statistics, 154(5).

Gingras, Y. (2012). Le champ scientifique. In F. Lebaron, \& G. Mauger (Eds.). Lectures de Bourdieu (pp. 279-294). Paris: Ellipses.

Godechot, O., \& Mariot, N. (2004). Les deux formes du capital social: Structure relationnelle des jurys de thèses et recrutement en science politique. Revue française de sociologie, $45(2), 243-282$.

Hjellbrekke, J. (2018). Multiple Correspondence Analysis for the Social Sciences. Oxford \& New York: Routledge.

Hjellbrekke, J., \& Korsnes, O. (2016). Women in the Field of Power. Sociologica, 2, 1-28.

Horowitz, M., \& Hughes, R. (2017). Political Identity and Economists' Perceptions of Capitalist Crises. Review of Radical Political Economics, 50(1): 173-193.

Jost, H. U. (2016). Von Zahlen, Politik und Macht. Geschichte der schweizerischen Statistik. Zurich: Chronos Verlag.

Kaplan, N. (1965). The Norms of Citation Behavior: Prolegomena to the Footnote. American Documentation, 16(3), 179-84.

Klüger, E. (2018). Mapping the Inflections in the Policies of the Brazilian National Economic and Social Development Bank during the 1990s and 2000s within Social Spaces and Networks. Historical Social Research, 43(3), 274-302.

Larivière, V., Macaluso, B., Archambault, É., \& Gingras, Y. (2010). Which Scientific Elites? On the Concentration of Research Funds, Publications and Citations. Research Evaluation, 19(1), 45-53.

Larsen, A. G., \& Ellersgaard, C. H. (2018). A Scandinavian Variety of Power Elites? Key Institutional Orders in the Danish Elite Networks. In O. Korsnes, J. Hjellbrekke, M. Savage, J. Heilbron, \& F. Bühlmann (Eds.), New Directions in Elite Studies (pp. 133-149). Oxford \& New York, Routledge.

Larsen, A. G., Ellersgaard, C. H., \& Andrade, S. (2016). Package 'soc.ca'. Link: https:// cran.r-project.org/web/packages/soc.ca/soc.ca.pdf.

Le Roux, B., \& Rouanet, H. (2010). Multiple Correspondence Analysis. Los Angeles: SAGE Publications Inc.

Lebaron, F. (2000). La croyance économique. Les économistes entre science et politique. Paris: Editions du Seuil. 
Lebaron, F. (2001). Economists and the Economic Order. The Field of Economists and the Field of Power in France. European Societies, 3(1), 91-110.

Lebaron, F. (2018). Economie, science et champ du pouvoir. Propos recueillis par Alizé Papp et Jules-Rémy Sarant. Regards croisés sur l'économie, 22(1), 215-223.

Lenoir, R. (2015). La notion de capital social dans l'œuvre de Pierre Bourdieu. Regards Sociologiques, 47-48, 109-132.

Lunding, J. A., Ellersgaard, C. H., \& Larsen, A. G. (2020). The Established and the Delegated: The Division of Labour of Domination among Effective Agents on the Field of Power in Denmark. Sociology, online first: https://journals.sagepub.com/doi/ full/10.1177/0038038520928220.

Mach, A. (2002). Economists as Policy Entrepreneurs and the Rise of Neoliberal Ideas in Switzerland during the 1990s. Economic Sociology: European Electronic Newsletter, 4(1), 3-16.

Maesse, J. (2015). Economic Experts: A Discursive Political Economy of Economics. Journal of Multicultural Discourses, 10(3), 279-305.

Mills, C. W. (1956). The Power Elite. New York: Oxford University Press.

Ötsch, W. O., Pühringer, S., \& Hirte, K., 2018, Netzwerke des Marktes: Ordoliberalismus als Politische Ökonomie. Wiesbaden: Springer VS.

Rossier, T. (2017). Affirmation et transformations des sciences économiques en Suisse au XXe siècle. $\mathrm{PhD}$ dissertation, University of Lausanne.

Rossier, T. (2019). Prosopography, Networks, Life Course Sequences, and so on. Quantifying with or beyond Bourdieu? Bulletin of Sociological Methodology, 144: 6-39.

Rossier, T., \& Bühlmann, F. (2018). The Internationalisation of Economics and Business Studies: Import of Excellence, Cosmopolitan Capital or American Dominance? Historical Social Research, 43(3), 189-215.

Rossier, T., Bühlmann, F., \& Mach, A. (2017). The Rise of Professors of Economics and Business Studies in Switzerland: Between Scientific Reputation and Political Power. European Journal of Sociology, 58(2), 295-326.

Savage, M., Warde, A., \& Devine, F. (2005). Capitals, Assets, and Resources: Some Critical Issues. British Journal of Sociology, 56(1), 31-47.

Schmidt-Wellenburg, C. (2018). Struggling over Crisis. Discoursive Positionings and Academic Positions in the Field of German-Speaking Economists. Historical Social Research, 43(3), 147-188.

Schmidt-Wellenburg, C., \& Lebaron, F. (2018). There Is No Such Thing as "the Economy". Economic Phenomena Analysed from a Field-Theoretical Perspective. Historical Social Research, 43(3), 7-38.

Serino, M., D’Ambrosio, D., \& Ragozini, G. (2017). Bridging Social Network Analysis and Field Theory through Multidimensional Data Analysis: The Case of the Theatrical Field. Poetics, 62, 66-80.

Wagner, A.-C. (2010). Le jeu de la mobilité et de l'autochtonie au sein des classes supérieures. Regards sociologiques, 40, 89-98. 


\section{Power and Influence of Economists}

Contributions to the Social Studies of Economics

Edited by Jens Maesse, Stephan Pühringer, Thierry Rossier and Pierre Benz 


\section{Power and Influence of Economists}

Economists occupy leading positions in many different sectors, including central and private banks, multinational corporations, the state and the media, as well as serve as policy consultants on everything from health to the environment and security. Power and Influence of Economists explores the interconnected relationship between power, knowledge and influence which has led economics to be both a source and beneficiary of widespread power and influence.

The contributors to this book explore the complex and diverse methods and channels that economists have used to exert and expand their influence from different disciplinary and national perspectives. Four different analytical views on the role of power and economics are taken: first, the role of economic expert discourses as power devices for the formation of influential expertise; second, the logics and modalities of governmentality that produce power/knowledge apparatuses between science and society; third, economists as involved in networks between academia, politics and the media; and fourth, economics considered as a social field, including questions of legitimacy and unequal relations between economists based on the accumulation of various capitals. The volume includes case studies on a variety of national configurations of economics, such as the US, Germany, Italy, Switzerland, Greece, Mexico and Brazil, as well as international spaces and organisations such as the IMF.

This book provides innovative research perspectives for students and scholars of heterodox economics, cultural political economy, sociology of professions, network studies and the social studies of power, discourse and knowledge.

Jens Maesse is Assistant Professor at the Department of Sociology at the University of Giessen, Germany.

Stephan Pühringer is Postdoctoral Research Associate at the Institute for Comprehensive Analysis of the Economy (ICAE) at the University of Linz, Austria, and Research Fellow at the Institute of Economics at the Cusanus University of Bernkastel-Kues, Germany.

Thierry Rossier is Postdoctoral Research Fellow at the Department of Organization at the Copenhagen Business School, Denmark.

Pierre Benz is Postdoctoral Researcher at the University of Applied Sciences and Arts Western Switzerland, Faculté of Social Work (HETSL | HES-SO), Switzerland. 


\section{Routledge Frontiers of Political Economy}

Markets, Community, and Just Infrastructures

Nancy Neiman

The Informal Economy

Measures, Causes, and Consequences

Ceyhun Elgin

Understanding Financial Crises

Ensar Yilmaz

The Political Economy of Populism

An Introduction

Petar Stankov

Capitalism, Institutions and Social Orders

The Case of Contemporary Spain

Pedro M. Rey-Araújo

Power and Influence of Economists

Contributions to the Social Studies of Economics

Edited by Jens Maesse, Stephan Pühringer, Thierry Rossier and Pierre Benz

Rent-Seeking and Human Capital

How the Hunt for Rents is Changing Our Economic and Political Landscape

Kurt von Seekamm Jr.

The Political Economy of State Intervention

Conserving Capital over the West's Long Depression

Gavin Poynter

For more information about this series, please visit: www.routledge.com/ books/series/SE0345 
First published 2022

by Routledge

2 Park Square, Milton Park, Abingdon, Oxon OX14 4RN

and by Routledge

605 Third Avenue, New York, NY 10158

Routledge is an imprint of the Taylor E Francis Group, an informa business

(C) 2022 selection and editorial matter, Jens Maesse, Stephan Pühringer, Thierry Rossier and Pierre Benz; individual chapters, the contributors

The right of Jens Maesse, Stephan Pühringer, Thierry Rossier and Pierre Benz to be identified as the authors of the editorial material, and of the authors for their individual chapters, has been asserted in accordance with sections 77 and 78 of the Copyright, Designs and Patents Act 1988.

The Open Access version of this book, available at www.taylorfrancis.com, has been made available under a Creative Commons Attribution-Non Commercial-No Derivatives 4.0 license.

Trademark notice: Product or corporate names may be trademarks or registered trademarks, and are used only for identification and explanation without intent to infringe.

British Library Cataloguing-in-Publication Data

A catalogue record for this book is available from the British Library

Library of Congress Cataloging-in-Publication Data

A catalog record has been requested for this book

ISBN: 978-0-367-41984-4 (hbk)

ISBN: 978-0-367-56595-4 (pbk)

ISBN: 978-0-367-81708-4 (ebk)

Typeset in Bembo

by Apex CoVantage, LLC

The open access publication of this book has been published with the support of the Swiss National Science Foundation. 